\title{
Genetic Mutation Analysis Can Supplement Clinically Confirmed Hereditary Hemorrhagic Telangiectasia Populations
}

\author{
Seon Tae Kim (D) \\ Department of Otolaryngology, Gil Medical Center, Gachon University College of Medicine, Incheon, Korea
}

Hereditary hemorrhagic telangiectasia (HHT), also known as Osler-Weber-Rendu disease, is a rare vascular disease diagnosed using the Curaçao diagnostic criteria: (1) recurrent nosebleeds (epistaxis), (2) cutaneous or mucosal telangiectasia, (3) visceral arteriovenous malformations (AVMs), and (4) an appropriate family history [1]. The prevalence of HHT is approximately 1 in 5,000-8,000 worldwide [2]. The most common clinical symptom of HHT patients is epistaxis, affecting more than $90 \%$ of HHT patients; the average age of onset is 12 years [3]. Large AVMs in the lung, liver, and central nervous system can cause life-threatening complications [2]. Six genetic loci including four identified genes and two genetic loci are reported to be associated with HHT. Mutations in two genes encoding transforming growth factor beta (TGF- $\beta$ ) receptors, endoglin (ENG) and activin A receptor like type 1 (ACVRL1/ALK1), result in clinically indistinguishable HHT1 and HHT2, respectively [4]. More than $80 \%$ of HHT patients have heterozygous mutations in these genes [5].

Koenighofer et al. [6] identified three unpublished, five known, and one silent variant in ENG and ACVRL1 from eight unrelated, nonconsanguineous families in Austria. Two novel variants and one known variant were identified in the ENG mutation. In the ACVRL1 mutation, one unpublished and three known variants were identified. The gene mutation study revealed nonsense, frameshift, splice donor, and missense variants [6]. These patterns are similar to those reported in previous studies from other countries.

Several genetic studies have investigated the correlations between genetic mutations and clinical phenotypes outcomes in HHT patients. The overall mutation rate in 14 Chinese Han patients with HHT-associated pulmonary hypertension was $71.4 \%$, including eight ACVRL-1 mutations and two ENG mutations, six of which were novel [7]. The case records of $21 \mathrm{HHT}$ patients indicate that mutations in the ENG, ACVRL1, and $S M A D 4$ genes result in different HHT phenotypes. The prevalence of pulmonary AVM is higher in HHT type 1, whereas hepatic AVMs are more common in HHT2 [8]. Seventy-eight patients included 53 HHT1 patients and 25 HHT2 patients. Pulmonary and brain AVMs were predominantly observed in HHT1 whereas hepatic AVMs were detected in HHT2 [9]. Two ENG and one ACVRL1 mutations were identified in three Korean families: a known ENG mutation, a novel ENG mutation, and a novel ACVRL1 mutation [10]. In a national mutation study among Danish patients with HHT, $80 \%$ of the patients were diagnosed clinically based on the Curaçao criteria, and the remaining patients were diagnosed by genetic testing [11].

All these studies suggest that ethnicity and regionality play a limited role in the clinical presentation and genetic mutation of HHT. HHT patients are primarily diagnosed by clinical signs according to the Curaçao criteria; however, some patients are diagnosed as possible HHT with only clinical symptoms from the criteria. Genetic analysis is thus recommended to diagnose HHT in these patients. Additional pathogenic mutation studies will further supplement the diagnostic rates in HHT patients.

\section{CONFLICT OF INTEREST}

No potential conflict of interest relevant to this article was reported.

\section{ORCID}

Seon Tae Kim https://orcid.org/0000-0002-2010-2843

Copyright (C) 2019 by Korean Society of Otorhinolaryngology-Head and Neck Surgery.

This is an open-access article distributed under the terms of the Creative Commons Attribution Non-Commercial License (http://creativecommons.org/licenses/by-nc/4.0)

which permits unrestricted non-commercial use, distribution, and reproduction in any medium, provided the original work is properly cited. 


\section{REFERENCES}

1. Shovlin CL, Guttmacher AE, Buscarini E, Faughnan ME, Hyland RH, Westermann CJ, et al. Diagnostic criteria for hereditary hemorrhagic telangiectasia (Rendu-Osler-Weber syndrome). Am J Med Genet. 2000 Mar;91(1):66-7.

2. Shovlin CL. Hereditary haemorrhagic telangiectasia: pathophysiology, diagnosis and treatment. Blood Rev. 2010 Nov;24(6):203-19.

3. AAssar OS, Friedman CM, White RI Jr. The natural history of epistaxis in hereditary hemorrhagic telangiectasia. Laryngoscope. 1991 Sep;101(9):977-80.

4. McAllister KA, Grogg KM, Johnson DW, Gallione CJ, Baldwin MA, Jackson CE, et al. Endoglin, a TGF-beta binding protein of endothelial cells, is the gene for hereditary haemorrhagic telangiectasia type 1. Nat Genet. 1994 Dec;8(4):345-51.

5. Abdalla SA, Letarte M. Hereditary haemorrhagic telangiectasia: current views on genetics and mechanisms of disease. J Med Genet. 2006 Feb;43(2):97-110.

6. Koenighofer M, Parzefall T, Frohne A, Allen M, Unterberger U, Laccone F, et al. Spectrum of novel hereditary hemorrhagic telangiectasia variants in an austrian patient cohort. Clin Exp Otorhinolaryngol. 2019 Nov;12(4):405-11.
7. Chen YJ, Yang QH, Liu D, Liu QQ, Eyries M, Wen L, et al. Clinical and genetic characteristics of Chinese patients with hereditary haemorrhagic telangiectasia-associated pulmonary hypertension. Eur J Clin Invest. 2013 Oct;43(10):1016-24.

8. Karlsson T, Cherif H. Mutations in the ENG, ACVRL1, and SMAD4 genes and clinical manifestations of hereditary haemorrhagic telangiectasia: experience from the Center for Osler's Disease, Uppsala University Hospital. Ups J Med Sci. 2018 Sep;123(3):153-7.

9. Komiyama M, IshiguroT, Yamada O, Morisaki H, MorisakiT. Hereditary hemorrhagic telangiectasia in Japanese patients. J Hum Genet. 2014 Jan;59(1):37-41.

10. Kim MJ, Kim ST, Lee HD, Lee KY, Seo J, Lee JB, et al. Clinical and genetic analyses of three Korean families with hereditary hemorrhagic telangiectasia. BMC Med Genet. 2011 Oct;12:130.

11. Torring PM, Brusgaard K, Ousager LB, Andersen PE, Kjeldsen AD. National mutation study among Danish patients with hereditary haemorrhagic telangiectasia. Clin Genet. 2014 Aug;86(2):123-33. 